The economically workable oil deposits of the world yield crude petroleums giving from 20 to 70 per cent of motor-spirit ; the crude distillates produced from British coals by coal-oil distillation give 35-45 per cent or more; thus they fall in the middle of the range, on a par, for example, with Southern California oil stock. We should also recollect two further points. First, the hazards of extracting coal from the coal measures are, in general, considerably less than those of extracting petroleum from oil deposits. These latter hazards may be visualized by recalling that nearly a third of the million or so oil wells drilled in the U.S.A. are stated to be dead or abandoned. Secondly, the world's total reserves of motor-spirit to be extracted from coal are considerably larger than those to be extracted from petroleum.

There is another aspect of the question. The coal-oil distillation process yields a considerable amount of high-grade smokeless fuel. Thus its development might serve a triple function. It might in the first place (like any other satisfactory process of obtaining motor-spirit from coal) render Great Britain less dependent on external supplies of motor-spirit. In the second place, at any rate so long as tax discrimination in favour of home-produced motor-spirit is continued, it opens up the possibility of establishing an export trade in cheap smokeless fuel, thus helping materially to relieve unemployment and economic distress in the coal industry. In the third place, like any other process yielding cheap smokeless fuel, it holds out a hope of ridding Britain of much of the smoke which is not only productive of so much waste and material damage, but also so destructive both of health and of amenity. It is clear that we are entering on a new phase as regards coal. In the first, pre-industrial stage, coal was little more than a curiosity-a combustible mineral which here and there was used in preference to wood. In the second place, coal became the mainspring of industry, but was regarded simply as a fuel. In the third phase, now dawning, we must accustom ourselves to think of coal as a raw material generally demanding special treatments for its proper utilization. The new concern for health and social welfare is demanding that methods for preventing smoke shall be adopted, even if at some economic sacrifice. Coal-owners and public alike must learn to regard coal as a store of riches which it is for science and technology to unlock and make available.

\section{Bureau of Animal Population}

THE modest report of the Bureau for 1936-37 contains much of practical as well as of scientific interest, and this is vouched for by the contributions made towards its upkeep by the Medical Research Council, the Forestry Commission, the Agricultural Research Council, Imperial Chemical Industries Ltd., the Partridge Research Fund, and Hudson's Bay Company Ltd. At the same time, these varied patronages suggest something of the extent of interests served by Mr. Elton and his colleagues. The research on vole populations in itself touches upon many interests: fluctuations in numbers of voles are of immediate concern to the farmer and forester, and to the ecologist they present problems still awaiting solution; the discovery of a disease closely resembling tuberculosis in a large proportion (22 per cent) of voles trapped in areas ranging from the north-east of Scotland to Buckinghamshire, may give a clue to the high death-rate which closes a vole plague, and may have some relationship with human and bovine tuberculosis. These and other vole matters are engaging the attention of a strong team of scientific workers. Research on partridge fluctuations continues, and from 1938 for a period of three years at least, data are to be collected and a much-needed analysis is to be made on the periodic fluctuations of rabbits and hares in Great Britain. It says something for the desirability of scientific investigation and propaganda, that in the report from the Select Committee of the House of Lords on Agriculture (Damage by Rabbits), running to some 270,000 words, less than a hundred were devoted to research.

APART from its British inquiries, the Bureau has given its help to investigations in North America on fluctuations in numbers of the snowshoe rabbit, an arctic wild-life inquiry, and on the evidence in the Hudson's Bay Company's archives of a ten-year cycle in fur-bearing animals. The only unsatisfactory feature of the report is concerned with finance. Although in this respect the position of the Bureau seems more assured than in former years, the fact that it is kept in being by grants drawn from fourteen different sources, suggests that the collecting of moneys must occupy an undesirably large proportion of the time and energy of the scientific worker responsible for its organization, and that the staff must be labouring under some uncertainty as to their future. Neither condition is conducive to the best scientific work, and we look forward to a day when the Bureau will become an integral part of a Stateorganized biological survey.

\section{The Ebro and $\mathrm{Zi}-\mathrm{Ka}$-wei Observatories}

IT has been from time to time a pleasure during the protracted civil war in Spain to receive the Boletin del Observatorio del Ebro and to realize that the famous Jesuit observatory was working away peacefully in Republican Spain. Father Rodés and his staff have been carrying on their heliophysical, meteorological and seismological work steadily with support from the Government-last year their grant was paid in full-the autonomous Government of Catalonia and the municipal councils of Villanova and Geltru, though they have been faced with severe difficulty in securing necessary scientific material and have been naturally unable to collect meteorological data from their observers scattered throughout Spain. Now comes the sad news, reported by the Burgos correspondent of The Times (April 25), that the tide of war has swept over them and that instruments have been dismantled and damaged during the hostilities, while the director, Father Rodés, has been taken to Barcelona. It is to be hoped that he will soon be released and enabled to return to his 